\title{
An Historic Caddo Burial at the Swen Farm Site (41BW65), Bowie County, Texas
}

Timothy K. Perttula

Heritage Research Center, Stephen F. Austin State University

Follow this and additional works at: https://scholarworks.sfasu.edu/ita

Part of the American Material Culture Commons, Archaeological Anthropology Commons, Environmental Studies Commons, Other American Studies Commons, Other Arts and Humanities Commons, Other History of Art, Architecture, and Archaeology Commons, and the United States History Commons

Tell us how this article helped you.

This Article is brought to you for free and open access by the Center for Regional Heritage Research at SFA ScholarWorks. It has been accepted for inclusion in Index of Texas Archaeology: Open Access Gray Literature from the Lone Star State by an authorized editor of SFA ScholarWorks. For more information, please contact cdsscholarworks@sfasu.edu. 


\section{An Historic Caddo Burial at the Swen Farm Site (41BW65), Bowie County, Texas \\ Creative Commons License \\ (c) (i) (8)}

This work is licensed under a Creative Commons Attribution-NonCommercial 4.0 International License 


\title{
An Historic Caddo Burial at the Swen Farm Site (41BW65), Bowie County, Texas
}

\author{
Timothy K. Perttula
}

\section{Introduction}

The Swen Farm site is on an alluvial terrace (220-230 ft. amsl) of the Sulphur River. When it was first recorded in 1970 prior to the enlargement of Lake Wright Patman the landform was an island in the reservoir, with the submerged channel of the river along the eastern and northern sides of the island, with artifacts of Archaic, Woodland, and ancestral Caddo period age exposed in several areas, and midden deposits were also present (Briggs and Malone 1970). In 1971, an early $18^{\text {th }}$ century Caddo burial feature was discovered at the site by L. H. Head, Sr., of Texarkana, Texas. Larry Head, Jr., then a college student at The University of Texas, assisted with the excavation of this burial feature and the recovery of associated grave goods (Head 1972).

\section{Burial Feature and Associated Grave Goods}

The burial feature was first exposed in a south-facing cut bank at the site, where the base of one grog-tempered ceramic vessel and pieces of a small grog-tempered plain ceramic jar were noted, along with a number of glass beads, a ceramic elbow pipe, and a gunflint. Troweling of the bank exposed occipital fragments from a human skull and additional glass beads at ca. $46 \mathrm{~cm}$ bs.

The ceramic elbow pipe and the ceramic jar rested ca. $20-25 \mathrm{~cm}$ west of the skull, while the base of the other vessel was ca. $30 \mathrm{~cm}$ south of the skull. The glass beads were concentrated between the two ceramic vessels and just south of the skull. Head (1972) suggests the beads may have been worn as a necklace or had been sewn onto the upper chest area of an article of clothing; this presumes that the skull faced generally to the south.

Other possible associated artifacts recovered in the immediate vicinity of the skull reported by Head (1972) included small lead shot, deer teeth, one human tooth and fragments of human tooth enamel, and one large mussel shell. A piece of "angular, hematitic stone" was found ca. $20 \mathrm{~cm}$ east of the skull.

The glass beads collected from the Swen Farm site burial include 1150 specimens. The beads include eight small white opaque beads of compound construction (No. 45 in the Harris and Harris (1967) Bead Chart, five clear, small, donut-shaped beads of simple construction (No. 49), and approximately 1137 small blue, opaque, and donut-shaped garter bead of simple construction (No. 47).

\section{Summary and Conclusions}

The remnants of an ancestral Caddo burial feature had been excavated in 1971 in a cut bank of a Sulphur River alluvial terrace at the Swen Farm site, where it had been exposed by erosion of the waters of Lake Texarkana (now Lake Wright Patman). The burial feature contained only human tooth and skull fragments as well as several funerary offerings, among them a ceramic elbow pipe, portions of two ceramic vessels, and approximately 1150 small white, clear, and blue glass beads of Types No. 45, 47, and 49 in the Harris and Harris (1967) Bead Chart. Their analysis of a number of other Historic Caddo and Wichita sites in Texas and Oklahoma indicate that these types of beads, which they refer to as garter 
beads (Harris and Harris 1967:156), are found on sites dating from ca. A.D. 1700-1740 in the early part of the Historic period. Type No. 47, however, is suggested to date from ca. A.D. 1740-1767. Several ancestral Nasoni Caddo burials dating from ca. A.D. 1700-1740 have also been found at the nearby Atlanta State Park site, but the glass beads found in the Caddo burials there were primarily medium-sized blue opaque barrel-shaped beads ( Harris et al. 1980:236).

\section{References Cited}

Briggs, A. K. and J. Malone

1970 Texarkana Reservoir Enlargement. Archeological Survey Report No. 7. Texas Historical Survey Committee, Austin.

Harris, R. K. and I. M. Harris

1967 Trade Beads, Projectile Points, and Knives. In A Pilot Study of Wichita Indian Archeology and Ethnohistory, assembled by R. E. Bell, E. B. Jelks, and W. W. Newcomb, pp. 129-162. Final Report for Grant GS-964. National Science Foundation, Washington, D.C.

Harris, R. K., I. M. Harris, and M. P. Miroir

1980 The Atlanta State Park Site in Northeastern Texas. Louisiana Archaeology 6:231-239.

Head, L. H., Jr.

1972 An Historic Burial at Swen Farm, LHBW50, Lake Texarkana. MS on file, Texas Archeological Research Laboratory, The University of Texas at Austin. 